\title{
Thermal and ultrasonic influence in the formation of nanometer scale hydroxyapatite bio-ceramic
}

\author{
This article was published in the following Dove Press journal: \\ International Journal of Nanomedicine \\ 22 September 2011 \\ Number of times this article has been viewed
}

\author{
GJE Poinern' \\ R Brundavanam' \\ X Thi Le' \\ $S$ Djordjevic \\ M Prokic ${ }^{2}$ \\ D Fawcett ${ }^{\prime}$ \\ 'Murdoch Applied Nanotechnology \\ Research Group, Department \\ of Physics, Energy Studies and \\ Nanotechnology, School of \\ Engineering and Energy, Murdoch \\ University, Murdoch, Western \\ Australia, Australia; ${ }^{2} \mathrm{MP}$ Inter \\ Consulting, Le Locle, Switzerland
}

Correspondence: GJE Poinern Murdoch Applied Nanotechnology Research Group, Department of Physics, Energy Studies and Nanotechnology, School of Engineering and Energy,

Murdoch University, Murdoch, Western Australia 6150, Australia

Tel +6I 893602892

Fax +6I 893606183

Email g.poinern@murdoch.edu.au

\begin{abstract}
Hydroxyapatite (HAP) is a widely used biocompatible ceramic in many biomedical applications and devices. Currently nanometer-scale forms of HAP are being intensely investigated due to their close similarity to the inorganic mineral component of the natural bone matrix. In this study nano-HAP was prepared via a wet precipitation method using $\mathrm{Ca}\left(\mathrm{NO}_{3}\right)_{2}$ and $\mathrm{KH}_{2} \mathrm{PO}_{4}$ as the main reactants and $\mathrm{NH}_{4} \mathrm{OH}$ as the precipitator under ultrasonic irradiation. $\mathrm{The} \mathrm{Ca} / \mathrm{P}$ ratio was set at 1.67 and the $\mathrm{pH}$ was maintained at 9 during the synthesis process. The influence of the thermal treatment was investigated by using two thermal treatment processes to produce ultrafine nano-HAP powders. In the first heat treatment, a conventional radiant tube furnace was used to produce nano-particles with an average size of approximately $30 \mathrm{~nm}$ in diameter, while the second thermal treatment used a microwave-based technique to produce particles with an average diameter of $36 \mathrm{~nm}$. The crystalline structure and morphology of all nanoparticle powders produced were investigated using X-ray diffraction (XRD), field emission scanning electron microscopy (FESEM), transmission electron microscopy (TEM), and Fourier transform infrared spectroscopy (FT-IR). Both thermal techniques effectively produced ultrafine powders with similar crystalline structure, morphology and particle sizes.
\end{abstract}

Keywords: nano-hydroxyapatite, chemical synthesis, ultrasonic irradiation, microwave irradiation

\section{Introduction}

The skeletal system is vital for the support and locomotion of the human body; it is constructed of cartilaginous materials and a hard natural tissue; bone. Bone is a complex organic-inorganic ceramic composite consisting of organic collagen fibrils containing well-arrayed embedded inorganic nano-crystalline rod- and plate-like materials ranging in size from 25 to $50 \mathrm{~nm}$ in length. ${ }^{1,2}$ Naturally occurring hydroxyapatite (HAP) is a mineral with a hexagonal structure that is composed of calcium phosphate groups with a general formula of $\mathrm{Ca}_{10}(\mathrm{OH})_{2}\left(\mathrm{PO}_{4}\right)_{6}$ for the unit cell. Both crystallographic and chemical studies have shown that synthetic HAP is similar to the natural occurring inorganic component found in the bone matrix and teeth. Because of this close similarity there has been an extensive research effort to employ synthetic HAP as a bone substitute and/or replacement in several biomedical applications. ${ }^{3,4}$

There are several significant advantages in using synthetic HAP in hard tissue engineering applications; it has good biocompatibility and bioactivity properties with respect to bone cells and other body tissues, a slow biodegradability in situ and it also offers good osteoconductivity and osteoinductivity capabilities. ${ }^{5-7}$ These properties are very important because bone tissue constantly undergoes remodelling, a process 
whereby bone tissue is simultaneously replaced and removed by the bone cells, (osteoblasts and osteoclasts, respectively). An investigation by Taniguchi et al has shown that sintered HAP exhibited an excellent biocompatible response to soft tissue such as skin, muscle, and gums. ${ }^{8}$ It is this type of response that has made synthetic HAP an ideal candidate for orthopedic and dental implants. Current hard tissue engineering applications include bone repair, bone augmentation, coating of metal implants, and as filler material for both bone and teeth. ${ }^{9-11}$ Unfortunately, due to its low mechanical strength, the use of pure HAP ceramics is restricted to low load bearing clinical applications. In some cases, combining HAP with other materials, such as polymers and/or glasses to form a composite, can alleviate these deficiencies. Materials such as high-density polyethylene and polypropylene can be used to improve the load-bearing capabilities of HAP. ${ }^{12,13}$

In addition, the complex structure of HAP has the added advantage of providing a very good absorption matrix for a variety of pharmaceutical products such as antibiotics, drugs, enzymes, hormones, and steroids. Both HAP-antibiotic and HAP-drug composites have been successfully used for the slow release of pharmaceutical products in situ. ${ }^{14-16}$ This type of drug delivery platform has proven to be effective in the treatment of diseases such as osteomyelitis, osteoporosis and osseous cancer, where the slow and sustained release of pharmaceuticals such as antibiotics has enhanced recovery from the disease. ${ }^{17}$

Recent and continuing research in nanotechnology and tissue engineering has highlighted the need to investigate the formation of HAP in the nanometer size range and clearly define its properties at this scale. This is essential in nanotechnology, because matter at the nanometer scale can have significantly different physicochemical properties. ${ }^{18-21}$ Significant improvements in the properties of HAP can be seen when the material is synthesized in the nanoscale range. ${ }^{22-25}$ For example, in a HAP particle study conducted by Sun et al on the influence of particle size on in vivo osteoblast cells, it was discovered that the inflammatory response was inhibited when smaller particle sizes $(0.5-3.0 \mu \mathrm{m})$ were used. ${ }^{22}$ Cells are generally in the micron-size range; however, their component structures and associated environment are in the nanometer to sub-micron range. In fact, the molecular building blocks of life: proteins, carbohydrates, nucleic acids, and lipids are all nanoscale structures. It is the crucial interaction between the cell and nanostructures such as proteins that is responsible for controlling cell functions such as proliferation, migration, and the production of the extracellular matrix. Importantly, it is the physical structure and chemistry of the nanostructure that directly influences the behaviour of the cell in contact with the surface. For example, the cell-substrate interaction is highly dependent on the nature of surface properties such as surface charge, surface chemistry, ${ }^{26}$ wettability, ${ }^{27}$ surface density of cell-binding ligands, ${ }^{28}$ and nanotopography. ${ }^{29,30}$ A major function of tissue engineering is to create an environment that can promote productive and efficient cellular activity. This is where nanotechnology has a significant role to play, since it permits the individualized creation of a scaffold structure that can be maximized for optimal environmental conditions specific to bone cells. Therefore, for any meaningful development in the future therapeutic use of nano-hydroxyapatite (nano-HAP)-based scaffold structures in the medical field, efficient manufacturing techniques are needed to produce large quantities of nano-HAP with well-defined chemical and physical properties.

Historically, several techniques were developed and have been used to manufacture HAP and calcium phosphate ceramics. These diverse techniques include homogeneous precipitation, ${ }^{31,32}$ sol-gel, ${ }^{33}$ plasma spray, ${ }^{34}$ hydrothermal, ${ }^{35}$ and ultrasonic spray freeze drying processes. ${ }^{36}$ The most attractive technique mentioned above is the sol-gel process. This wet chemical method is based on a simple and straightforward procedure that can economically produce HAP without the need for expensive specialized equipment. Moreover, this technique can be easily scaled up to meet high demands. However, the main difficulty encountered in using this technique is being able to effectively control the size and morphology of the resulting nanoparticles to within a specific parameter range. The fine-tuning of both size and morphology is crucial in determining the properties of the resulting nano-HAP powders.

Wet chemical techniques can produce crystalline materials from solutions, but a subsequent thermal treatment at elevated temperatures is required to produce specific crystalline phases. The particle size and morphology of HAP produced using this technique can be controlled by varying the experimental conditions that regulate nucleation, the aging process, and the growth kinetics of the particles. The controlling parameters that are used to produce monophase HAP are the initial reactants, the preparation temperature, and the $\mathrm{pH}$ value. Using a wet chemical method, Khopade et $\mathrm{al}^{37}$ and $\mathrm{An}$ et $\mathrm{al}^{38}$ were able to produce HAP particles that had a plate-like structure or morphology, in stark contrast to the spherical HAP particles produced under the influence of ultrasonic irradiation.

The precipitation method is the most commonly used wet chemical technique for producing either homogeneous 
or inhomogeneous calcium phosphate ceramics. ${ }^{39}$ It should also be mentioned that the electronic properties of HAP are sensitive to several variables such as $\mathrm{Ca} / \mathrm{P}$ ratios, structural defects, crystal size, temperature, and the preparation procedures used to produce the HAP. ${ }^{40}$ Several chemical routes have been used to manufacture HAP with diverse results; the deviation from the normal HAP phase can be significant and is technique dependent. ${ }^{41}$ In addition, the presence of other molecules in the synthesis process can influence the type of HAP phase produced. This influencing effect has been used by Wang et al to create a molecular template for producing HAP nanorods. ${ }^{42}$

The properties of nanocrystalline HAP produced using a hydrothermal process was investigated by Guo and Xiao, whose study revealed that particle size decreased as the thermal treatment temperature increased. ${ }^{43} \mathrm{~A}$ similar study by Meissner et al indicated that the size and morphology of the synthesized HAP could be controlled and that both size and morphology were dependent on the precipitation temperature and the ultrasound power used. ${ }^{44}$ The relationship between particle size and temperature was also investigated by Laquerriere et al who were able to demonstrate particle size reduction with increasing thermal treatment temperatures. ${ }^{45}$ The dependence of ultrasonic irradiation on both particle size and morphology was investigated and confirmed by Li-Yun et al when they were able to produce a monophase nano-HAP material using a $300 \mathrm{~W}$ ultrasound transducer. ${ }^{46}$

The wet milling process is an important procedure carried out during sample preparation. The use of ultrasonic irradiation during wet milling is an efficient means of dispersing and de-agglomerating the sample particles during the grinding process. The sonochemical effects which produce acoustic cavitations, promote both chemical reactions and physical effects that directly influence particle morphology during the growth phase. The major advantages of using ultrasonic irradiation during the manufacture of superfine particle slurries are: (1) increased reaction speed, (2) decreased processing time, and (3) an overall improvement in the efficient use of energy. ${ }^{47}$ In previous chemical precipitation techniques, the authors investigated several reactants with varying degrees of success in controlling the particle size and morphology. In this paper, we study a recently developed chemical route that uses calcium nitrate tetrahydrate $\left(\mathrm{Ca}\left[\mathrm{NO}_{3}\right]_{2} \cdot 4 \mathrm{H}_{2} \mathrm{O}\right)$ and potassium dihydrogen phosphate $\left(\mathrm{KH}_{2} \mathrm{PO}_{4}\right)$ as the main reactant materials. The control of the $\mathrm{pH}$ during the synthesis process was achieved by the addition of ammonium hydroxide $\left(\mathrm{NH}_{4} \mathrm{OH}\right){ }^{48}$

This paper also undertakes to examine the thermal influence of two thermal treatment techniques used in the formation of nano-HAP from the precursor nuclide formed in the wet synthesis process. The first thermal technique uses a conventional tube furnace while the second uses a microwave oven. Microwave heating differs significantly from the heating mechanism that occurs in a conventional furnace. In the furnace, energy travels through the material, via the thermal conduction of heat from the surface towards the centre of the material. This type of heating process produces a large thermal gradient from the surface to the centre of the material. In particular, if the material is a poor thermal conductor the thermal gradient can be quite high. The advantage of using microwave heating arises from the way the energy is volumetrically introduced throughout the material; this is fundamentally different to the thermal conduction mechanism that occurs in a radiant conventional furnace. . $^{49,50}$

\section{Materials and methods Materials}

HAP powders were synthesized from calcium nitrate tetrahydrate $\left(\mathrm{Ca}\left[\mathrm{NO}_{3}\right]_{2} \cdot 4 \mathrm{H}_{2} \mathrm{O}\right)$ and potassium di-hydrogen phosphate $\left(\mathrm{KH}_{2} \mathrm{PO}_{4}\right)$ as the main reactant materials. The $\mathrm{pH}$ control of the solutions was achieved by the addition of ammonium hydroxide $\left(\mathrm{NH}_{4} \mathrm{OH}\right)$. All analytical grade reagents used in this work were supplied by Chem-Supply Pty Ltd (Gillman, South Australia, Australia). The ultrasound processor was an UP50H $(50 \mathrm{~W}, 30 \mathrm{kHz}, \mathrm{MS} 7$ Sonotrode (7 $\mathrm{mm}$ diameter, $80 \mathrm{~mm}$ length)) supplied by Hielscher Ultrasound Technology (Teltow, Germany). All solutions were made using Milli-Q ${ }^{\circledR}$ water $\left(18.3 \mathrm{M} \Omega \mathrm{cm}^{-1}\right.$; Millipore Corporation, Billerica, MA).

\section{Methods}

\section{Synthesis of initial nano-HAP crystallites}

The synthesis of nano-HAP was begun by placing a $40 \mathrm{~mL}$ solution of $0.32 \mathrm{M} \mathrm{Ca}\left(\mathrm{NO}_{3}\right)_{2} \cdot 4 \mathrm{H}_{2} \mathrm{O}$ into a small beaker. The solution $\mathrm{pH}$ was then adjusted to 9.0 with approximately $2.5 \mathrm{~mL}$ ammonium hydroxide. The solution was then exposed to ultrasonic irradiation, with the processor set at maximum amplitude for 1 hour. At the end of the first hour a $60 \mathrm{~mL}$ solution of $0.19 \mathrm{M}\left[\mathrm{KH}_{2} \mathrm{PO}_{4}\right]$ was then slowly added dropwise into the first solution while undergoing a second hour of ultrasonic irradiation. During the mixing process, the $\mathrm{pH}$ value was checked and maintained at 9 while the $\mathrm{Ca} / \mathrm{P}$ ratio was maintained at 1.67 . The solution was then filtered using centrifugation $(\sim 2000 \mathrm{~g})$, after which the resultant white precipitate was proportioned into a number of samples for heat treatment. There were two sample sets made, the first consisting of twelve samples for thermal treatment in the 
tube furnace and the second consisting of five samples for microwave treatment.

\section{Thermal treatment process}

The two thermal treatment processes used to investigate the thermal influence in the formation of nano-HAP powders were a conventional electric tube furnace and a standard domestic microwave oven. In the case of the electric tube furnace, the white precipitate samples were placed into ceramic boats before being positioned in the furnace for thermal treatment. During treatment, the reaction temperatures varied between samples and ranged from $100^{\circ} \mathrm{C}$ to $400^{\circ} \mathrm{C}$ over specific time periods. For example, samples heated at $100^{\circ} \mathrm{C}$ required a 12-hour treatment period, while samples heated at temperatures of $200^{\circ} \mathrm{C}, 300^{\circ} \mathrm{C}$, and $400^{\circ} \mathrm{C}$ had a 2 -hour period. The longer reaction time for the $100^{\circ} \mathrm{C}$ samples was necessary to produce both crystalline and harder nano-HAP powders. This was necessary because earlier studies with shorter thermal treatment periods had produced nano-HAP powders with a consistent soft, mixed crystalline and amorphous structure. A total of twelve samples were treated, each sample matched a respective power setting of the ultrasound processor and thermal reaction temperature used (see Table 1). The second thermal treatment process used a standard domestic household microwave (1100 W at $2450 \mathrm{MHz}$; LG ${ }^{\circledR}$, Eastern Creek, New South Wales, Australia). The five precipitate samples were each placed into a fused silica crucible, which was supplied by Rojan Advanced Ceramics Pty Ltd (Henderson, Western Australia, Australia). Then in turn, each crucible with sample was placed into the microwave for thermal treatment. A 40-minute treatment period was used for all samples, with each sample matched to a respective percentage power

Table I Furnace thermal treatment at different times and ultrasound power used during the synthesis process

\begin{tabular}{llll}
\hline Sample & $\begin{array}{l}\text { Ultrasound power } \\
(\%) \text { (Maximum } \\
\text { amplitude) }\end{array}$ & $\begin{array}{l}\text { Thermal } \\
\text { treatment } \\
\text { temperature }\left({ }^{\circ} \text { C) }\right.\end{array}$ & $\begin{array}{l}\text { Treatment } \\
\text { duration } \\
\text { (hours) }\end{array}$ \\
\hline S-I & 100 & 100 & 12 \\
S-2 & 100 & 200 & 2 \\
S-3 & 100 & 300 & 2 \\
S-4 & 100 & 400 & 2 \\
S-5 & 50 & 100 & 12 \\
S-6 & 50 & 200 & 2 \\
S-7 & 50 & 300 & 2 \\
S-8 & 50 & 400 & 2 \\
S-I & 0 & 100 & 12 \\
S-II & 0 & 200 & 2 \\
S-III & 0 & 300 & 2 \\
S-IV & 0 & 400 & 2 \\
\hline
\end{tabular}

setting (see Table 3). The general processing procedure and the respective thermal treatments are schematically presented in Figure 1.

\section{Characterization}

At the end of each thermal treatment the sample ended up as a white agglomerated mass. Once cooled, the material was milled to form a fine powder, which was subsequently characterized using X-ray diffraction spectroscopy (XRD), Field Emission Scanning Electron Microscopy (FESEM), Transmission Electron Microscopy (TEM), and Fourier Transform Infrared (FT-IR) techniques. Powder XRD spectra were recorded at room temperature, using a Siemens D500 series diffractometer (Siemens, Munich, Germany), $\left(\mathrm{Cu} \mathrm{K} \mathrm{K}_{\alpha}=1.5406 \AA\right.$ radiation source) operating at $40 \mathrm{kV}$ and $30 \mathrm{~mA}$. The diffraction patterns were collected over a $2 \theta$ range from $20^{\circ}$ to $60^{\circ}$ with an incremental step size of $0.04^{\circ}$ using flat plane geometry. The acquisition time was 2 seconds. The powder XRD spectrum was used to identify the purity of the final nano-HAP powders and any other phases that were present. The crystalline size of the particles in the powders was calculated using the Debye-Scherrer equation (Equation 1) from the respective XRD patterns and estimated from the corresponding FESEM micrographs.

The morphological and macrostructural features of the nano-HAP powders were investigated using FESEM. All micrographs were taken using a high resolution FESEM (Zeiss 1555 VP-FESEM; Carl Zeiss AG, Oberkochen, Germany) at $3 \mathrm{kV}$ with a $30 \mu \mathrm{m}$ aperture operating under a pressure of $1 \times 10^{-10}$ Torr. FT-IR spectroscopy investigations were carried out using a Bruker Optics IFS 66 series FT-IR spectrometer (Bruker Optik Gmbh, Ettlingen, Germany). The KBr pellet technique was used, in which $2 \mathrm{~g}$ of nano-HAP powder was mixed with 5-10 $\mathrm{g}$ of spectroscopic grade $\mathrm{KBr}$ and then compressed at around $15 \mathrm{kPa}$ to form a disk. In addition, the

Table 2 Nano-HAP particle sizes obtained from XRD and FESEM in terms of ultrasound power and thermal treatment temperature

\begin{tabular}{|c|c|c|c|c|c|}
\hline \multicolumn{2}{|c|}{ Particle size $(\mathrm{nm} \pm 5 \%)$} & \multicolumn{4}{|c|}{ Temperature } \\
\hline Technique & $\begin{array}{l}\text { Ultrasound } \\
\text { power (W) }\end{array}$ & $100^{\circ} \mathrm{C}$ & $200^{\circ} \mathrm{C}$ & $300^{\circ} \mathrm{C}$ & $400^{\circ} \mathrm{C}$ \\
\hline \multirow[t]{3}{*}{ XRD } & 0 & 230 & 230 & 230 & 180 \\
\hline & 25 & 88 & 44 & 36 & 32 \\
\hline & 50 & 58 & 35 & 30 & 25 \\
\hline \multirow[t]{3}{*}{ FESEM } & 0 & 150 & 140 & 170 & 130 \\
\hline & 25 & 72 & 60 & 43 & 36 \\
\hline & 50 & 48 & 40 & 28 & 26 \\
\hline
\end{tabular}

Abbreviations: HAP, hydroxyapatite; XRD, X-ray diffraction; FESEM, field emission scanning electron microscopy. 
Table 3 Nano-HAP particle sizes produced with respect to microwave power setting

\begin{tabular}{lll}
\hline Sample & $\begin{array}{l}\text { Microwave } \\
\text { power }(\%)\end{array}$ & $\begin{array}{l}\text { Mean particle } \\
\text { size }(\mathbf{n m} \pm \mathbf{5 \%})\end{array}$ \\
\hline M-I & 20 & 37 \\
M-2 & 40 & 37 \\
M-3 & 60 & 36 \\
M-4 & 80 & 35 \\
M-5 & 100 & 35 \\
\hline
\end{tabular}

Note: Samples prepared using an ultrasound power of $50 \mathrm{~W}$.

Abbreviation: HAP, hydroxyapatite.

FESEM micrographs were also used to estimate the nano-HAP particle size by graphically measuring the size of each particle. The particle size of every particle in a $500 \mathrm{~nm}$ square grid was measured and then the mean particle size was determined from the data. All FT-IR spectra data was recorded in the range from $400 \mathrm{~cm}^{-1}$ to $4000 \mathrm{~cm}^{-1}$ in steps of $4 \mathrm{~cm}^{-1}$. The resulting spectra were then analyzed using the OMNIC ${ }^{\circledR}$ software package (Thermo Fisher Scientific, Waltham, MA).

In addition, each sample thermally treated using the microwave technique was also examined using TEM. This technique was used to elucidate the formation of spherical crystalline agglomerations formed under the influence of the microwave-induced thermal treatment. Prior to TEM examination, the sample nano-HAP powder was dispersed in ethyl alcohol using a low-powered sonic bath. Once thoroughly dispersed, a drop of the suspension was deposited onto a carbon-coated copper TEM grid using a micro pipette and then allowed to slowly dry over a 24-hour period. After sample preparation a bright field TEM study was carried out using a Phillips CM-100 electron microscope (Philips Corporation, Eindhoven, the Netherlands) operating at $80 \mathrm{kV}$.

\section{Results}

\section{X-ray diffraction spectroscopy}

The crystalline phases of all samples were found to be consistent with phases incorporated in the ICDD (International Centre for Diffraction Data) databases. The XRD patterns for all 12 samples thermally treated in the tube furnace at different treatment temperatures (as detailed in Table 1) are presented in Figure 2. Figure 2A presents the XRD patterns of samples (S-I to S-IV) that were synthesized without the assistance of ultrasonic irradiation. In contrast, Figure $2 \mathrm{~B}$ presents the XRD patterns of samples (S-1 to S-8) that were synthesized in the presence of ultrasonic irradiation. The main $(\mathrm{h} \mathrm{k} 1)$ indices for HAP are: (0 $\left.0 \begin{array}{ll}0 & 2\end{array}\right),\left(\begin{array}{lll}2 & 1 & 1\end{array}\right),\left(\begin{array}{lll}1 & 1 & 2\end{array}\right),\left(\begin{array}{lll}3 & 0 & 0\end{array}\right),\left(\begin{array}{lll}2 & 0 & 2\end{array}\right),\left(\begin{array}{lll}1 & 3 & 0\end{array}\right),\left(\begin{array}{l}2 \\ 2\end{array}\right.$ $\left.\begin{array}{l}2 \\ 2\end{array}\right),\left(\begin{array}{lll}2 & 1 & 3\end{array}\right)$, and ( $\left(\begin{array}{lll}0 & 0 & 4\end{array}\right)$ and are included in Figure $2 \mathrm{~A}$ and $\mathrm{B}$ to assist in the identification of the peaks.

The XRD patterns of samples S-I to S-IV in Figure 2A (no ultrasonic irradiation) show peaks with significant intensities in the $2 \theta$ range $23.4^{\circ}-23.7^{\circ}, 26.9^{\circ}-27.4^{\circ}$, and a much lower

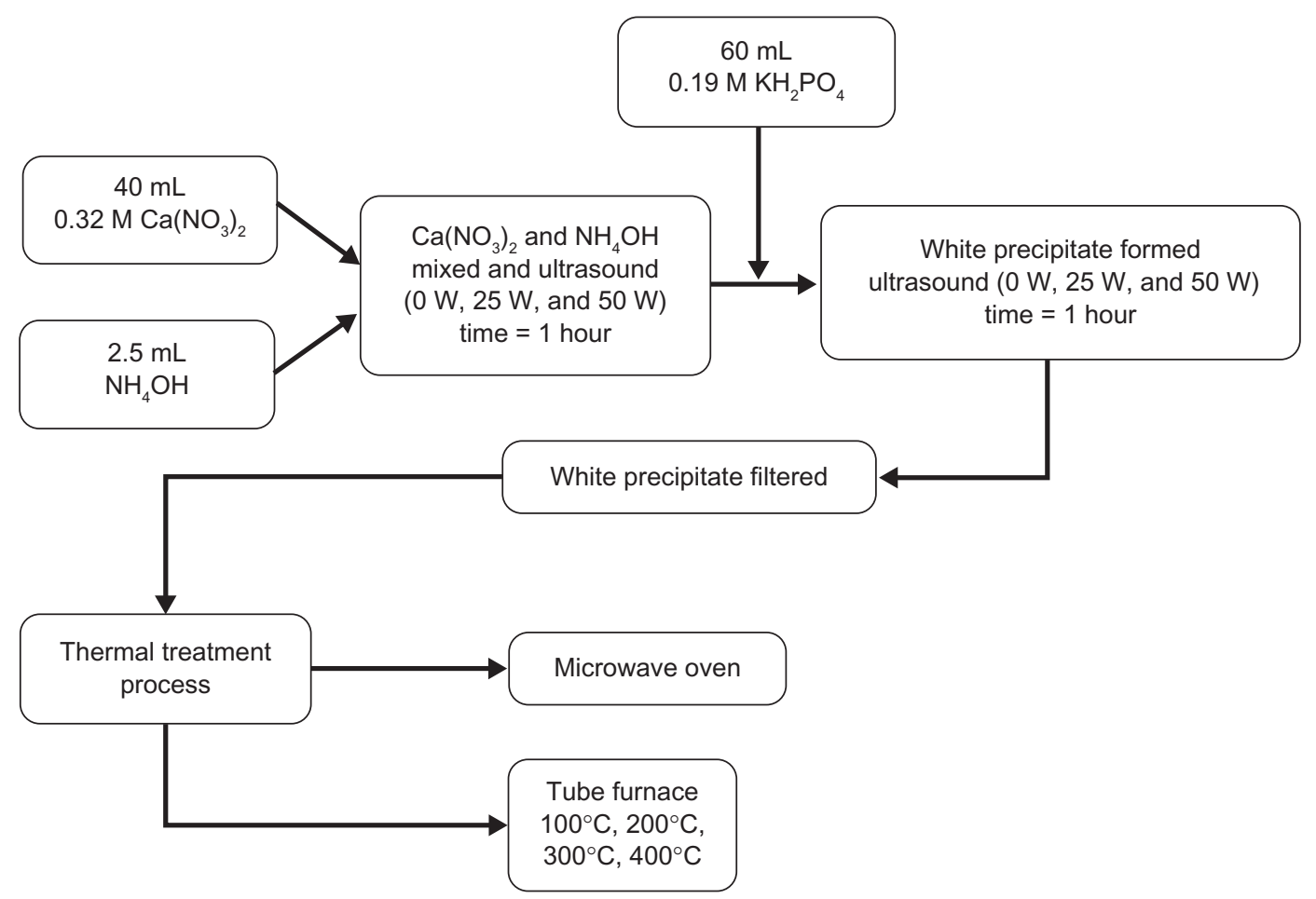

Figure I Schematic of experimental procedure for synthesizing nano-HAP. 

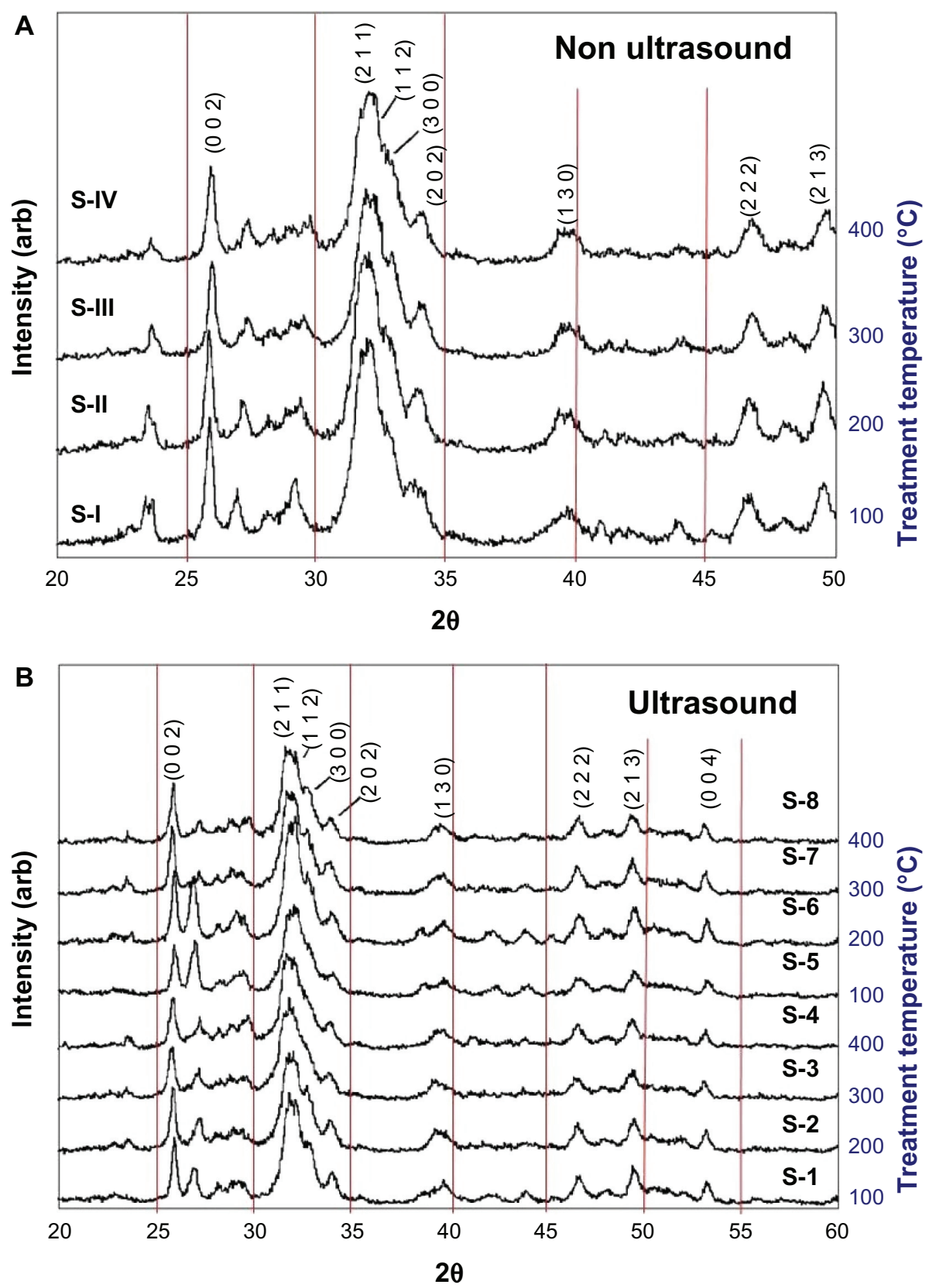

Figure 2 XRD patterns for nano-HAP powders prepared under different experimental conditions as listed in Table I. Notes: (A) No ultrasound: Samples S-I to S-IV, (B) Ultrasound: Samples S-I to S-8.

Abbreviations: XRD, X-ray diffraction; HAP, hydroxyapatite.

intensity peak at $40.4^{\circ}-40.9^{\circ}$. These peaks are consistent with the $\mathrm{CaH}_{2} \mathrm{P}_{2} \mathrm{O}_{7}$ phase (International Center for Diffraction Data, Joint Committee on Powder Diffraction Standards, CPDS No 41-0487). In addition, the intensities of these peaks are noticeably reduced in the sample thermally treated at $400^{\circ} \mathrm{C}$, which suggests that there is an impurity phase present in this predominately nano-HAP material. The XRD patterns of samples S-1 to S-8 in Figure 2B (ultrasonically irradiated) show peaks with a significant reduction in the intensities for the $2 \theta$ range $23.4^{\circ}-23.7^{\circ}$ when compared to similar peaks in Figure $2 \mathrm{~A}$. There was very little change in peak intensity for samples S-4 (100\% ultrasound power) and S-8 (50\% ultrasound power) for the $400^{\circ} \mathrm{C}$ treatment temperature. Also, the intensity of peaks found in the XRD patterns in the $2 \theta$ range $26.9^{\circ}-27.4^{\circ}$ for samples S-1 and S-5 $\left(100^{\circ} \mathrm{C}\right)$, and S-2 and S-6 $\left(200^{\circ} \mathrm{C}\right)$ shows significant enhancement. The intensity ratios of these peaks when compared to those found in the $23.4^{\circ}-23.7^{\circ}$ range, do not exactly match the $\mathrm{CaH}_{2} \mathrm{P}_{2} \mathrm{O}_{7}$ phase. The known 
calcium hydrogen phosphate phases, such as $\mathrm{CaH}_{4}\left(\mathrm{PO}_{3}\right)_{2} \cdot \mathrm{H}_{2} \mathrm{O}$ (JCPDS 46-0494), do not appear to be the impurity phases; since this would alter the intensity ratio of the $\left(\begin{array}{lll}0 & 0 & 2\end{array}\right)$ and $\left(\begin{array}{l}2 \\ 2\end{array}\right.$ 11 ) indexed HAP peaks significantly. A greatly reduced calcium dihydrogen diphosphate $\left(\mathrm{CaH}_{2} \mathrm{P}_{2} \mathrm{O}_{7}\right)$ phase, and possibly diammonium hydrogen phosphate, $\left(\mathrm{NH}_{4}\right)_{2} \mathrm{HPO}_{4}$ (Acta Crystallographica B28 [1972] 2065-2069) phase, seems to be present in the predominately HAP phase for samples thermally treated at $100^{\circ} \mathrm{C}$ and $200^{\circ} \mathrm{C}$. The $\left(\mathrm{CaH}_{2} \mathrm{P}_{2} \mathrm{O}_{7}\right)$ phase is a member of the crystalline and amorphous calcium phosphate family that often forms during the thermal treatment of HAP. ${ }^{51}$

The XRD patterns of samples (M-1 to M-5) thermally treated in the microwave oven are presented in Figure 3. All samples were synthesized in the presence of ultrasonic irradiation ( $50 \mathrm{~W}$ power setting) before being placed into the microwave for thermal treatment. A 40 min treatment period was used for all samples, with each sample being matched to a respective power setting (see Table 3 ). All sample XRD patterns revealed the presence of crystalline nano-HAP phases. These phases were found to be consistent with phases listed in the ICDD database, with the main (h k l) indices for nano-HAP: (l $\left.\begin{array}{lll}0 & 0 & 2\end{array}\right),\left(\begin{array}{lll}2 & 1 & 1\end{array}\right),\left(\begin{array}{lll}1 & 1 & 2\end{array}\right),\left(\begin{array}{lll}3 & 0 & 0\end{array}\right)$, (2 $\left.\begin{array}{ll}0 & 2\end{array}\right),\left(\begin{array}{lll}3 & 1 & 0\end{array}\right),\left(\begin{array}{lll}2 & 2 & 2\end{array}\right),\left(\begin{array}{lll}2 & 1 & 3\end{array}\right)$, and ( $\left.\begin{array}{lll}0 & 0 & 4\end{array}\right)$ being indicated in Figure 3. The patterns reveal significant peak intensities in the $2 \theta$ range between $26.9^{\circ}$ and $27.4^{\circ}$, which indicate the presence of the $\left(\mathrm{CaH}_{2} \mathrm{P}_{2} \mathrm{O}_{7}\right)$ phase (JCPDS No 41-0487).
Inspection of Figure 3 reveals that the peak intensities were generally reduced by increasing the microwave power, (from $20 \%$ to $100 \%$ ) whilst the nano-HAP peak at (002) steadily increased in intensity over this range. This thermal effect transformed the impure calcium apatite precursor phase into the pure nano-HAP phase. Comparing XRD patterns of samples S-4 and S-8, both thermally treated in the tube furnace at $400^{\circ} \mathrm{C}$, with sample M-5 that was thermally treated at $100 \%$ microwave power, we can see a remarkable resemblance between the XRD patterns.

The crystallite size, $t_{(h k l)}$, of the synthesized nano-HAP powders was calculated from the XRD pattern using the Debye-Scherrer equation. ${ }^{52-54}$

$$
t_{(h k l)}=\frac{0.9 \lambda}{B \cos \theta_{(h k l)}}
$$

where, $\lambda$ is the wavelength of the monochromatic X-ray beam, $B$ is the Full Width at Half Maximum (FWHM) of the peak at the maximum intensity, $\theta_{(h k l)}$ is the peak diffraction angle that satisfies Bragg's law for the (h k l) plane, and $t_{(h k l)}$ is the crystallite size.

The $\left(\begin{array}{lll}0 & 0 & 2\end{array}\right)$ reflection peak from the XRD pattern was used to calculate the average nano-HAP crystallite size from the Debye-Scherrer equation. The calculation was done so that a comparison could be made of the products produced by the various thermal treatment temperatures. The calculated

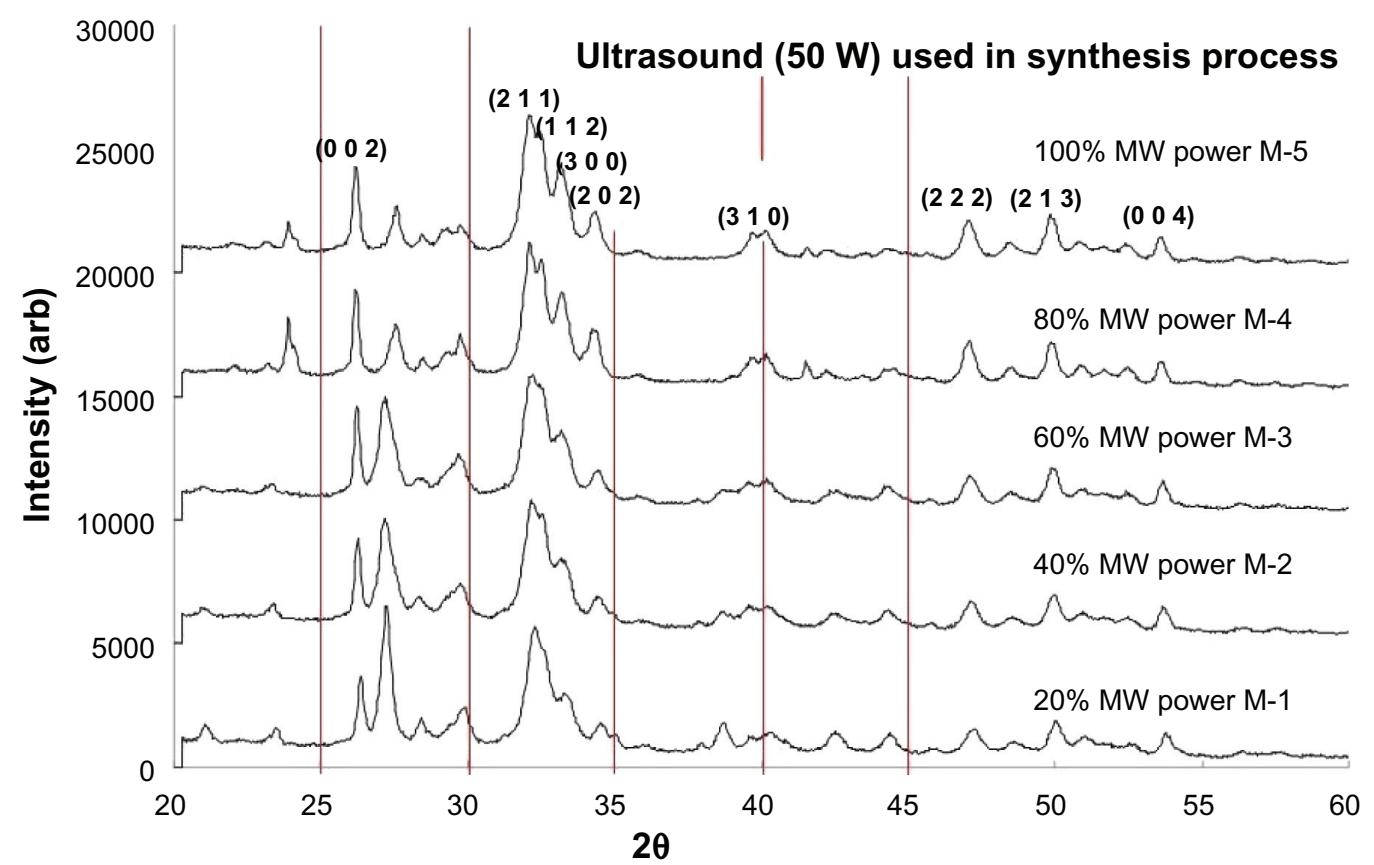

Figure 3 XRD patterns of nano-HAP powders prepared in the presence of $100 \%$ Ultrasound power and thermally treated in a microwave oven at various power settings. Abbreviations: XRD, X-ray diffraction; HAP, hydroxyapatite. 
crystallite sizes for samples thermally treated in the tube furnace are presented in Table 2, while the sizes for samples treated in the microwave are presented in Table 3.

\section{Field emission scanning electron microscopy and transmission electron microscopy examination of samples}

The FESEM microscopy technique was used to investigate the size and morphology of the nano-HAP powders produced in both cases. Figure 4 presents typical FESEM images of nano-HAP powders thermally treated in the tube furnace. The powders presented in Figure 4A and B were produced without ultrasound, while Figure $4 \mathrm{C}$ and $\mathrm{D}$ were synthesized in the presence of ultrasound. Inspection of all images reveals the presence of spherical particle morphology in all samples produced, this is similar to the particle morphologies reported in the literature. ${ }^{39,55-59}$ The mean particle sizes determined from the FESEM images are tabulated in Table 2. These particle sizes compare favorably with those calculated from the XRD spectra. At the lower temperatures of $100^{\circ} \mathrm{C}$ and $200^{\circ} \mathrm{C}$, the particle sizes show greater variation, $\left(17.2 \%\right.$ at $100^{\circ} \mathrm{C}$ and $14.3 \%$ at $\left.200^{\circ} \mathrm{C}\right)$ but at the higher temperatures the two techniques tend to give smaller particle sizes with decreasing variation $(6.7 \%$ at $300^{\circ} \mathrm{C}$ and $4.0 \%$ at $400^{\circ} \mathrm{C}$ ). This appears to be the influence of the shape and orientation of the particles being imaged in the FESEM compared to the sizes calculated from the XRD technique. At higher temperatures the thermal treatment produces a more uniform particle shape, orientation, and regularity; hence both FESEM and XRD techniques produce more consistent particle size data. Figure 5 presents

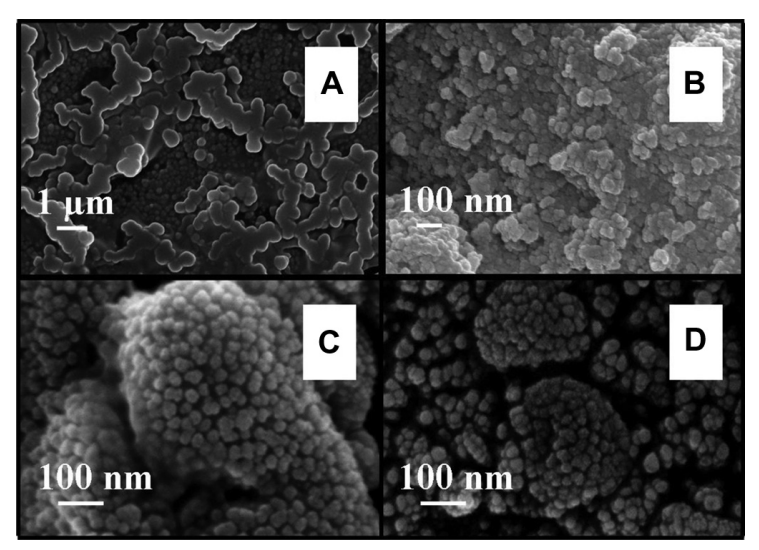

Figure 4 FESEM images of nano-HAP powder samples at various thermal treatment temperatures (scale bars shown in each image). (i) No ultrasound in preparation (A) $300^{\circ} \mathrm{C}$ and (B) $400^{\circ} \mathrm{C}$ (ii) Ultrasound used in preparation (C) $300^{\circ} \mathrm{C}$ and (D) $400^{\circ} \mathrm{C}$.

Abbreviations: FESEM, field emission scanning electron microscopy; HAP, hydroxyapatite.

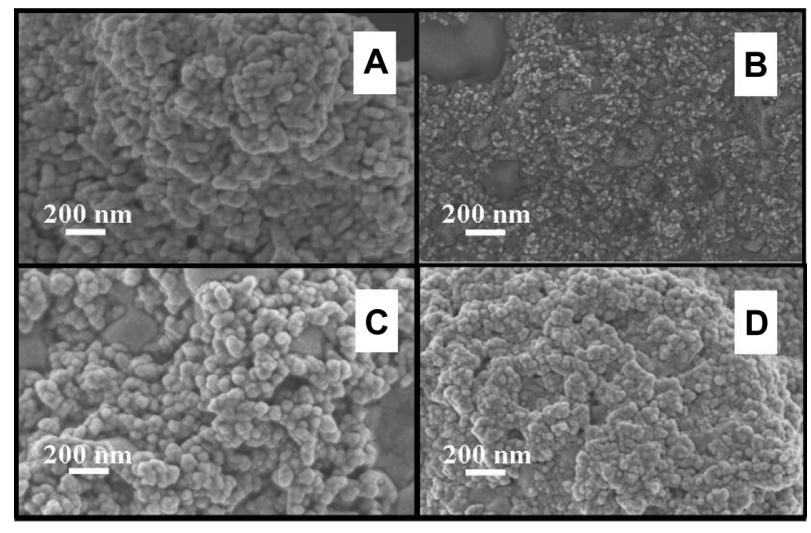

Figure 5 FESEM images of nano-HAP powder samples thermally treated in a microwave oven at various power settings (A) $20 \%$, (B) $60 \%$, (C) $80 \%$, and (D) $100 \%$ (scale bars shown in each image).

Abbreviations: FESEM, field emission scanning electron microscopy; HAP, hydroxyapatite.

a selection of FESEM images of nano-HAP powders thermally treated in the microwave oven at various power settings. All four images reveal the spherical morphology of the particles; they are highly agglomerated and have a mean size of around $36 \mathrm{~nm}$ (Table 3). A TEM study was undertaken to further investigate the spherical nature of the particles and agglomerating characteristic of the powders. A typical TEM micrograph of a nano-HAP powder thermally treated using a microwave oven at $100 \%$ power is presented in Figure 6. The micrograph confirms the spherical geometry of the particles and their agglomerating nature. The micrograph also confirms the size range of the particles $(26-43 \mathrm{~nm})$, with the mean particle size estimated to be $36 \mathrm{~nm}$.

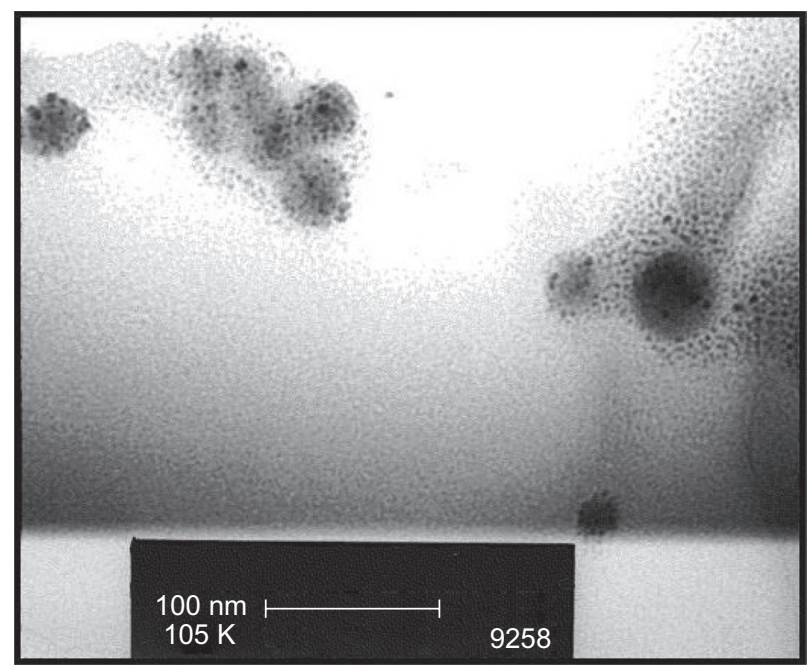

Figure 6 TEM micrograph of spherical crystalline agglomerations produced by microwave induced thermal treatment of nano-HAP powders.

Abbreviations: TEM, transmission electron microscopy; HAP, hydroxyapatite. 


\section{Fourier transform infrared examination of samples}

The thermal influence in the formation of nano-HAP of both the tube furnace and the microwave oven were investigated. Both thermal processes produce similar spectra, which confirm the presence of nano-HAP in the synthesized powders. Figure 7 presents a typical spectrum of nano-HAP powders thermally treated in the tube furnace, while Figure 8 shows the results of the thermal treatment performed in a microwave oven at five specific power settings. The FT-IR analysis was carried out to identify species, functional groups, and vibration modes associated with each peak. The following analysis was common to all samples thermally treated and was used to identify the presence of nano-HAP. To begin with, the bands occurring at $564 \mathrm{~cm}^{-1}$ and $601 \mathrm{~cm}^{-1}$ are the result of $v_{4}$ vibrations of the O-P-O mode. The two weaker peaks located at $725 \mathrm{~cm}^{-1}$ and $832 \mathrm{~cm}^{-1}$ are associated with the carbonate group and clearly indicate the presence of carbonates in the samples. The band located at $961 \mathrm{~cm}^{-1}$ is produced by the $v_{1}$ symmetric stretching vibrations of the $\mathrm{P}-\mathrm{O}$ mode. The very strong peaks located at $1032 \mathrm{~cm}^{-1}$ and $1092 \mathrm{~cm}^{-1}$ correspond to the $\mathrm{PO}_{4}^{3-}$ functional group, and the weaker peak at $1384 \mathrm{~cm}^{-1}$ corresponds to the $\mathrm{CO}_{3}{ }^{2-}$ functional group. The presence of the carbonate ion results from the interaction between atmospheric carbon dioxide and the nano-HAP precursor alkaline solution sample, this reaction has been seen in other studies. ${ }^{60-62}$ The smaller peak located at $1644 \mathrm{~cm}^{-1}$ also corresponds to a $\mathrm{CO}_{3}^{2-}$ group. The band located at $3432 \mathrm{~cm}^{-1}$ indicates the presence of absorbed water and the weak peak located at $3570 \mathrm{~cm}^{-1}$ corresponds to the vibrations of $\mathrm{OH}^{-}$ions in the nano-HAP lattice. This analysis indicates that both thermal treatment techniques produced nano-HAP powders of high quality.

\section{Discussion}

The XRD results for samples thermally treated in the tube furnace clearly indicate that the use of ultrasonic irradiation during the synthesis process has influenced the chemical interactions between the reacting species. This influence is believed to alter the rate of formation and chemical equilibrium of the calcium hydrogen phosphate phases. The results also revealed the presence of another chemical species, probably a form of calcium hydrogen phosphate, which was formed in significant amounts in samples thermally treated at $100^{\circ} \mathrm{C}$ and $200^{\circ} \mathrm{C}$. At higher thermal treatment temperatures such as $400^{\circ} \mathrm{C}$ there were insignificant amounts formed. Also, a close inspection of the XRD patterns presented in Figure 2 reveals that the $\left(\begin{array}{lll}0 & 0 & 2\end{array}\right)$ nano-HAP diffraction peak intensity remained fairly constant, but its width broadens as the thermal treatment temperature increases. Li-Yun et al has reported a slight decrease in the (lllll $\left.0 \begin{array}{ll}0 & 2\end{array}\right)$ nano-HAP peak intensity and explained that it was the result of a change in

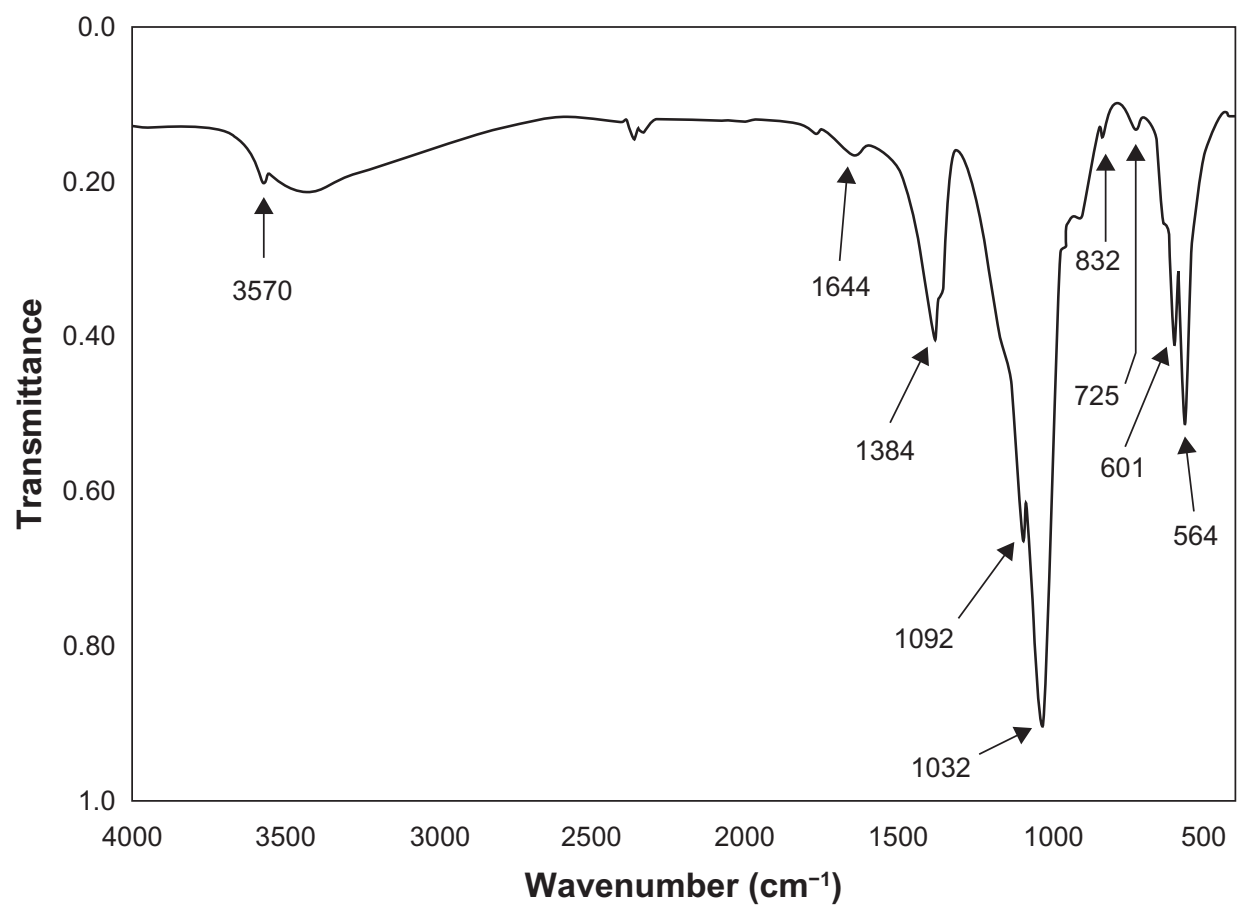

Figure 7 A typical FT-IR spectrum of a nano-HAP powder thermally treated in the tube furnace. Abbreviations: FT-IR, Fourier transform infrared; HAP, hydroxyapatite. 
Wavenumber $\left(\mathrm{cm}^{-1}\right)$

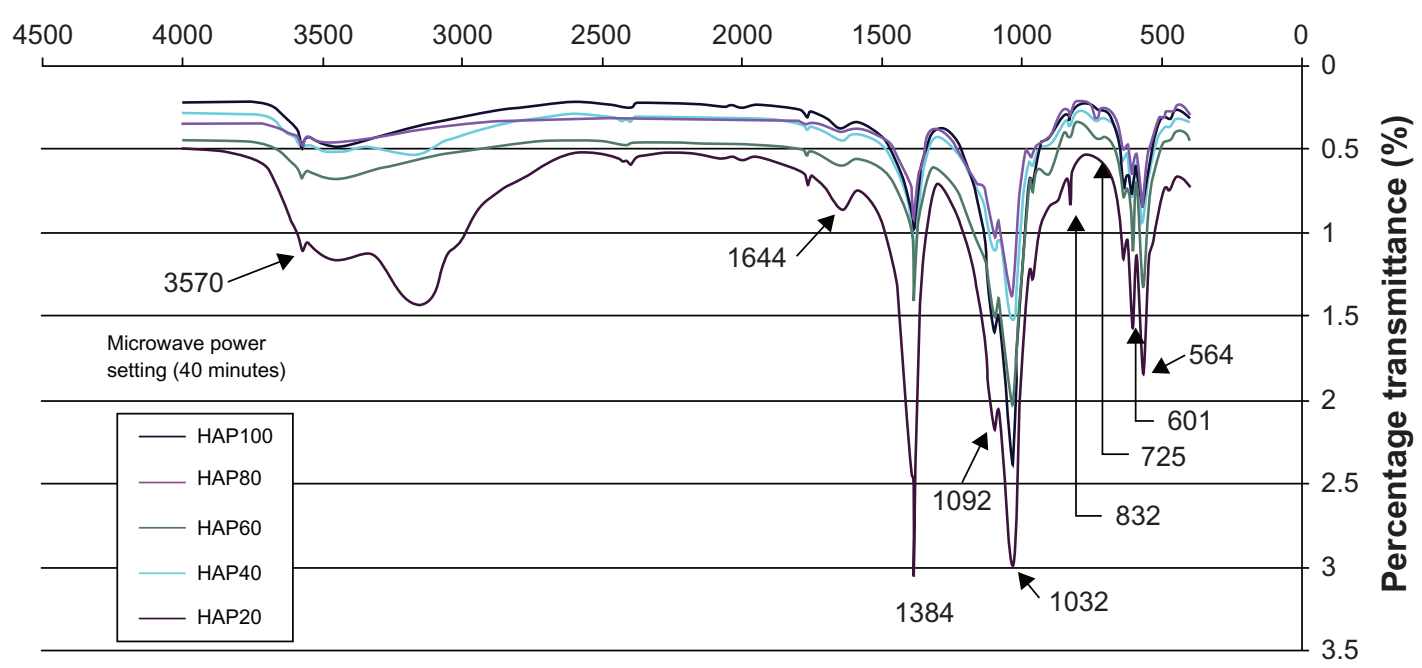

Figure 8 FT-IR spectra of nano-HAP powders thermally treated in the microwave oven at various power settings.

Abbreviations: FT-IR, Fourier transform infrared; HAP, hydroxyapatite.

the shape of the nano-HAP particles (acicular vs spherical). ${ }^{46}$ In this study, the $\left(\begin{array}{lll}0 & 0 & 2\end{array}\right)$ peak results indicate the presence of a particular particle shape common to all samples. Subsequent FESEM and TEM images confirm the presence of spherical particle geometry in all samples. Another interesting feature of the thermal treatment carried out in the tube furnace is the decrease in particle size with increasing treatment temperature. Furthermore, as the ultrasound power used in the synthesis process increases, the particle sizes of the nano-HAP crystallites decreases (see Table 2).

The second type of thermal influence investigated was the effect of microwave heating on nano-HAP particle formation. The $\left(\begin{array}{lll}0 & 0 & 2\end{array}\right)$ reflection peak from the microwave XRD patterns (Figure 3) was used to calculate the average nano-HAP crystallite size from equation 1 . The calculated particle sizes for samples M-1 to M-5 are presented in Table 3. The most striking difference between the two thermal treatments is the size range of the resulting nano-HAP crystallites. In the tube furnace, the particle size decreased with the increasing thermal treatment temperature, but in the case of the microwave oven treatment, the particle size remained relatively consistent across all power settings with a mean value of $36 \mathrm{~nm}$. This value is similar to the particle size obtained by Siddharthan et al using a microwave-based thermal treatment process. ${ }^{50}$

The presence of ultrasound in the synthesis procedure prior to the thermal treatment has a significant influence in forming the initial nano-HAP particle precursors. This is due to the particle size being related to nucleation and the growth pattern of the material, which in turn is related to the degree of super saturation within the liquid phase. The presence of ultrasonic irradiation in the synthesis process formed bubbles that grew and then implosively collapsed creating localized hot spots. These localised hot spots can reach temperatures of up to $5300 \mathrm{~K}$ and pressures around 500 atmospheres, which are then followed by rapid cooling rates often exceeding $1010 \mathrm{~K} / \mathrm{s} .{ }^{61}$ These extreme pressure and temperature variations promote both physical effects and chemical reactions that directly influence the synthesis of materials in the liquid phase. ${ }^{62}$ In addition, both the particle size and its morphology can be directly influenced during this synthesis process. The effect of increasing the ultrasound power from 0 to $50 \mathrm{~W}$ showed that it was possible to decrease the particle size prior to thermal treatment (see Table 2). The increasing ultrasound power used to irradiate the liquid indicated that greater numbers of bubbles/cavitations were being produced. This in turn produced more nucleation sites and as a result the particles formed around these sites are smaller. Furthermore, particles exposed to longer periods of ultrasonic irradiation show less agglomeration. Subsequent FESEM data has confirmed the reduced particle agglomeration when ultrasound is used during the synthesis process.

It is interesting to note that both thermal treatments produce nano-HAP particles that are spherical in nature and highly agglomerated. These characteristics have been confirmed by both FESEM images and TEM micrographs. The FESEM images of all nano-HAP powders were examined and then the mean particle size was determined. In the case of the tube furnace thermal treatment, there was a definite trend in the mean particle size decreasing with increasing 
treatment temperature. The FESEM results confirmed the same trend seen in the XRD analysis. The FESEM image analysis also confirmed that mean particle size decreased when the ultrasound power increased during the synthesis process (see Table 2). The FESEM images taken of particles synthesized in the presence of ultrasound and thermally treated in the microwave had a different size characteristic. In fact the mean particle size remained fairly constant across all power settings (see Table 3 ).

The results of the FT-IR analysis indicate that both thermal techniques have produced nano-HAP powders of high quality. The influence of microwave power on the thermal treatment process can be seen in Figure 8. Inspection of Figure 8 reveals some important differences in the spectra for each power setting, with the $20 \%$ power setting producing the most significant differences. Moving from left to right across Figure 8, we can see that the percentage transmittance in the range from 2400 to $3750 \mathrm{~cm}^{-1}$ for all power settings except the $20 \%$ is reasonably close. The larger transmittance for the $20 \%$ power setting is the result of a larger presence of absorbed water and the weak peak located at $3570 \mathrm{~cm}^{-1}$ corresponds to the vibrations of $\mathrm{OH}^{-}$ions in the nano-HAP lattice. The peaks located at $1644 \mathrm{~cm}^{-1}$ and $1384 \mathrm{~cm}^{-1}$ indicate the presence of the $\mathrm{CO}_{3}^{2-}$ function groups and we can see that $20 \%$ power setting has the largest presence of the $\mathrm{CO}^{2-}$ group while the $100 \%$ power setting has the lowest presence. The decrease in peak amplitude with increasing power suggests that during the thermal treatment the $\mathrm{CO}_{3}^{2-}$ group is being incorporated into the forming nano-HAP. The peaks located at $1032 \mathrm{~cm}^{-1}$ and $1092 \mathrm{~cm}^{-1}$, which correspond to the $\mathrm{PO}_{4}{ }^{3-}$ functional group, are noteworthy because both the $20 \%$ and $100 \%$ power setting are similar in amplitude. The remaining power settings have lower transmittance values. The peaks located at $725 \mathrm{~cm}^{-1}$ and $832 \mathrm{~cm}^{-1}$ are also associated with the carbonate group and tend to decrease with increasing power. The peaks located at $564 \mathrm{~cm}^{-1}$ and $601 \mathrm{~cm}^{-1}$, which result from the $v_{4}$ vibrations of the O-P-O mode, are also affected by the increasing power. The lower $20 \%$ power setting produced the greatest difference in transmittance, while the higher power settings all produced similar transmittance values.

The FT-IR analysis reveals that increasing the microwave power from $20 \%$ to higher settings significantly changes peak amplitudes. In the case of the $1384 \mathrm{~cm}^{-1}$ peak the higher powers all have similar transmittance, while at the $1032 \mathrm{~cm}^{-1}$ peak the $40 \%$ and $80 \%$ power settings have similar transmittance values. The $60 \%$ and $100 \%$ power settings have high transmittances, but are still lower than the $20 \%$ power setting. The changes in peak intensities indicate the transformation of an impure calcium apatite phase into the pure nano-HAP phase. This transformation was also seen in the XRD analysis.

This study has shown that there is a significant thermal and ultrasonic influence in forming nano-HAP. In terms of throughput, the combined ultrasound/microwave technique is superior to the conventional tube furnace for producing nanoHAP ultrafine powders. The technique used clearly demonstrates an economic route with a strong scale-up capability. An interesting feature of the ultrasound/microwave technique is that the particle size is fairly consistent across all power settings, which indicates that the current technique can only produce a mean particle size of $36 \mathrm{~nm}$. On the other hand, the thermal treatment performed in the tube furnace gave greater temperature control and produced temperature dependent particles sizes. The higher the thermal treatment temperature used, the smaller the particle size produced. It is interesting to note that the different heating effect produced by the microwave oven does not show any particle size dependence. Even when using a different microwave power setting each time over a fixed operating period (40 minutes) little effect was observed on the particle size. The exact mechanism that is occurring during the microwave thermal treatment needs to be further investigated.

\section{Conclusion}

Hydroxyapatite is a ceramic that is generally considered to be a viable substitute for bone material in many clinical biomedical and tissue engineering applications. In this study, the influence of ultrasound in the synthesis of nano-HAP powders was examined in conjunction with the type of thermal treatment used. Nano-HAP particles in the nanometer size range and spherical morphology were produced using a wet chemical precipitation technique in the presence of ultrasound. It was found that the crystalline structure and morphology of the resulting nano-HAP powders was dependent upon the power of the ultrasonic irradiation source and the subsequent thermal treatment used. It was evident that the presence of ultrasound in the synthesis process promoted the chemical reactions and physical effects that subsequently produced the ultrafine nanoHAP powders after thermal treatment. The thermal influence on the formation of ultrafine nano-HAP powders was investigated using two thermal treatment processes. The first used a conventional tube furnace and the second used a domestic microwave oven. The tube furnace gave greater temperature control, with higher treatment temperatures giving smaller particle sizes, unlike the microwave oven treatment which did 
not show any particle size dependence over the range of power settings. Both thermal treatments, in conjunction with the ultrasound-assisted synthesis process, produced nano-HAP powders with the same crystalline structure and morphology. The only difference arises in the size of the particles produced by the respective thermal treatment processes.

\section{Acknowledgments}

This work was partly supported by the Western Australian Nanochemistry Research Institute (WANRI). Dr Derek Fawcett would like to thank the Bill \& Melinda Gates Foundation for their research fellowship. The authors would also like to thank Mr Christopher Geagea for his helpful contributions.

\section{Disclosure}

The authors report no conflicts of interest in this work.

\section{References}

1. Weiner S, Wagner HD. The material bone: structure-mechanical function relations. Ann Rev Mater Sci. 1998;28:271-298.

2. Hellmich C, Ulm FJ. Average hydroxyapatite concentration is uniform in the extracollagenous ultrastructure of mineralized tissues: evidence at the 1-10 $\mu \mathrm{m}$ scale. Biomech Model Mechanobiol. 2003;2(1):21-36.

3. Hutmacher DW, Schantz JT, Lam CXF, Tan KC, Lim TC. State of the art and future directions of scaffold-based bone engineering from a biomaterials perspective. J Tissue Eng Regen Med. 2007;1:245-260.

4. Habraken WJ, Wolke JG, Jansen JA. Ceramic composites as matrices and scaffolds for drug delivery in tissue engineering. Adv Drug Deliver Rev. 2007;59(4-5):234-248.

5. Blom A. Which scaffold for which application? Curr Orthopaed. 2007; 21(4):280-287.

6. Habibovic P, de Groot K. Osteoinductive biomaterials-properties and relevance in bone repair. J Tissue Eng and Regen Med. 2007;1(1): 25-32.

7. Kalita SJ, Bhardwaj A, Bhatt HA. Nanocrystalline calcium phosphate ceramics in biomedical engineering. Materials Science and Engineering $C$. 2007;27(3):441-449.

8. Taniguchi M,Takeyema H, Mizunna I, et al. The clinical application of intravenous catheter with percutaneous device made of sintered hydroxyapatite. Japanese J Artificial Organs. 1991;20(2):460-464.

9. Silva RV, Camilli JA, Bertran JA, Moreira NH. The use of hydroxyapatite and autogenous cancellous bone grafts to repair bone defects in rats. Inter J Oral Maxillofacial Surg. 2005;34(2):178-184.

10. Stoch A, Jastrzebski W, Dlugon E, et al. Sol-gel derived hydroxapatite coatings on titanium and its alloy $\mathrm{Ti}_{6} \mathrm{Al}_{4} \mathrm{~V} . \mathrm{J}$ Mol Struct. 2005; 744-747:633-640.

11. Vecchio KS, Zhang X, Massie JB, Wang M, Kim CW. Conversion of bulk seashells to biocompatiable hydroxyapatite for bone implants. Acta Biomater. 2007;3(6):910-918.

12. Ono I, Tateshita T, Nakajima T. Evaluation of a high density polyethylene fixing system for hydroxyapatite ceramic implants. Biomaterials. 2000;21(2):143-151.

13. Bonner M, Ward IM. Hydroyapatite/polypropylene composite: a novel bone substitute material. J Mater Sci Lett. 2001;20(22):2049-2051.

14. Ginebra MP, Traykova T, Planell JA. Calcium phosphate cements as bone drug-delivery systems: a review. J Control Release. 2006;113(2): 102-110.

15. Schnieders J, Gbureck U, Thull R, Kissel T. Controlled release of gentamicin from calcium phosphate-poly(lactic acid-co-glycolic acid) composite bone cement. Biomaterials. 2006;27(23):4239-4249.
16. Baro M, Sanchez E, Delgado A, Perera A, Evora C. In vitro-in vivo characterisation of gentamicin bone implants. J Control Release. 2002; 83(3):353-364.

17. Cornell CN, Tyndall D, Waller S, Lane JM, Brause BD. Treatment of experimental osteomyelitis with antibiotic-impregnated bone graft substitute. J Orthop Res. 1993;11(5):619-626.

18. Ozine GA, Arsenault AC. Nanochemistry: A Chemical Approach to Nanomaterials. Cambridge, UK: Royal Society of Chemistry; 2005.

19. Guozhong C. Nanostructures and Nanomaterials: synthesis, properties and applications. London, UK: Imperial College Press; 2004.

20. Christenson EM, Anseth KS, van den Beucken JJ, et al. Nanobiomaterial applications in orthopaedics. J Orthop Res. 2007;25(1):11-22.

21. Kumar C. Nanodevices for the Life Sciences. Weinheim, Germany: Wiley-VCH; 2006.

22. Sun JS, Liu HC, Chang WHS, Li J, Lin FH, Tai HC. Influence of hydroxyapatite particle size on cell activities: an in vitro study. J Biomed Mater Res. 1998;39(3):390-397.

23. Pushpakanth S, Srinivasan B, Sreedhar B, Sastry TP. An in situ approach to prepare nanorods of titania-hydroxyapatite $\left(\mathrm{TiO}_{2}-\mathrm{HAp}\right)$ nanocomposite by microwave hydrothermal technique. Mater Chem Phys. 2008;107(2-3):492-498.

24. Wang X, Li Y, Wei J, de Groot K. Development of biomimetic nano-hydroxyapaptite/poly(hexamethylene adipamide) composites. Biomaterials. 2002;23(24):4787-4791.

25. Rusu VM, Ng CH, Wilke M, Tiersch B, Fratzl P, Peter MG. Size controlled hydroxyapatite nanoparticles as self organised organic-inorganic materials. Biomaterials. 2005;26(26):5414-5426.

26. Rappaport $\mathrm{C}$, Small aspect of the growth of mammalian cells on glass surfaces. In: Hair ML, editor. The Chemistry of Bio Surfaces. New York: Marcel Dekker; 1972:449-489.

27. Volger EA, Interfacial chemistry in biomaterials science. In: Berg JC, editor. Wettability. New York: Marcel Dekker; 1993:184-250.

28. Grinell F. Cellular adhesives and extracellular substrata. Int Rev Cytology, 1978;53:65-144.

29. Christenson EM, Anseth KS, Van den Beucken JP, et al. Nanobiomaterial applications in orthopedics. J Orthop Res. 2007;25(1):11-22.

30. Webster TJ, Smith TA, Increased osteoblast function on PLGA composites containing nanophase titania. J Biomed Mater Res A. 2005; 74(4):677-686.

31. Santos MH, Oliveira M, Palhares de Freitas L,Mansur HS, Vasconcelos WL. Synthesis control and characterisation of hydroxyapatite prepared by wet precipitation process. Materials Research. 2004;7(4)625-630.

32. Aizawa M, Ueno H, Itatani K, Okada I. Synthesis of calcium-deficient apatite fibres by a homogenous precipitation method and their characterizations. J Eur Cer Soc. 2006;26:501-507.

33. Panda RN, Hsieh MF, Chung RJ, Chin TS. FTIR, XRD, SEM and solid state NMR investigations of carbonate-containing hydroxyapatite nano-particles synthesised by hydroxide-gel technique. J Phys Chem Solids. 2003;64:193-199.

34. Park E, Condrate RA, Lee D. Infrared spectral investigation of plasma spray coated hydroxyapatite. Mater Lett. 1998;36:38-43.

35. Kannan S, Rocha JHG, Ventura JMG, Lemos AF, Ferreira JMF. Effect of $\mathrm{Ca} / \mathrm{P}$ ratio of precursors on the formation of different calcium apatite ceramics - an X-ray diffraction study. Scr Mater. 2005;53(11):1259-1262.

36. Itatani K, Iwafune K, Howell FS, Aizawa M. Preparation of various calcium-phosphate powders by ultrasonic spray freeze-drying technique. Mater Res Bull. 2000;35:575-585.

37. Khopade AJ, Khopade S, Jain NK. Development of haemoglobin aquasomes from spherical hydroxyapatite cores precipitated in the presence of half-generation poly(amidoamine) dendrimer. Int J Pharmaceutics. 2002;241(1):145-154.

38. An GH, Wang HJ, Kim BH, Jeong YG, Choa YH. Fabrication and characterization of a hydroxyapatite nanopowder by ultrasonic spray pyrolysis with salt-assisted decomposition. Mater Sci Eng A. 2007;449-451:821-824.

39. Bezzi G, Celotti G, Landi E, La Torretta TMG, Sopyan I,Tampieri A. A novel sol-gel technique for hydroxyapatite preparation. Materi Chem Phys. 2003;78:816-824. 
40. Jarudilokkul S, Tanthapanichakoon W, Boonamnuayvittaya V. Synthesis of hydroxyapatite nanoparticles using an emulsion liquid membrane system. Colloids and Surfaces A: Physicochem Eng Aspects. 2006;296:149-153.

41. Koutsopoulos S. Synthesis and characterization of hydroxyapatite crystals: a review study on the analytical methods. J Biomed Mater Res. 2002;62(4):600-612.

42. Wang Y, Zhang S, Wei K, Zhao N, Chen J, Wang X. Hydrothermal synthesis of hydroxapatite nanopowders using cationic surfactant as a template. Mater Lett. 2006;60:1484-1487.

43. Guo X, Xiao P. Effects of solvents on properties of nanocrystalline hydroxyapatite produced from hydrothermal process. J Eur Ceram Soc. 2006;26:3383-3391.

44. Meissner G, Oehme B, Strackeljan J, Kocher T. In vitro calculus detection with a moved smart ultrasonic device. J Clinical Periodontol. 2006;33(2):130-134

45. Laquerriere $\mathrm{P}$, Grandjean-Laquerriere A, Kilian L, et al. Influence of hydroxyapatite particle characteristics on the $[\mathrm{K}] /[\mathrm{Na}]$ ratio: a human monocytes In vitro study. Colloids Surf B: Biointerfaces. 2004; 33(1):39-44.

46. Li-Yun $\mathrm{C}$, Chuan-bo Z, Jian-feng $\mathrm{H}$. Influence of temperature, $\left[\mathrm{Ca}_{2+}\right]$, $\mathrm{Ca} / \mathrm{P}$ ratio and ultrasonic power on the crystallinity and morphology of hydroxyapatite nanoparticles prepared with a novel ultrasonic precipitation method. Mater Lett. 2005;59(14-15):1902-1906.

47. Hielscher Ultrasound Technology. Ultrasonic extraction and preservation. Copyright 1999-2007, by Hielscher ultrasonics Gmbh. Available at: http://www.hielscher.com/ultrasonics/extraction_01.htm. Accessed on September 7, 2011.

48. Poinern GEJ, Brundavanam RK, Mondinos N, Jiang ZT. Synthesis and characterisation of nanohydroxyapatite using an ultrasound assisted method. Ultrason Sonochem. 2009;16(4):469-474.

49. Vollmer M. Physics of the microwave oven. Phys Ed. 2004;39(1):74-81.

50. Siddharthan A, Seshadri SK, Sampath-Kumar TS. Influence of microwave power on nanosized hydroxyapatite particles. Scripta Mater. 2006;55(2):175-178.
51. Han Y, Li S, Wang X, Bauer I, Yin M. Sonochemical preparation of hydroxyapatite nanoparticles stabilized by glycosaminoglycans. Ultrason Sonochem. 2007;14(3):286-290.

52. Danilchenko SN, Kukharenko OG, Moseke C, Protsenko IY, Sukhodub LF, Sulkio-Cleff B. Determination of the bone mineral crystallite size and lattice strain from diffraction line broadening. Cryst Res Technol. 2002;37(11):1234-1240.

53. Klug HP, Alexander LE. X-ray diffraction procedures for crystalline and amorphous materials. 2nd edition. New York: Wiley;1974.

54. Barrett CS, Cohen JB, Faber J, et al. Advances in X-ray Analysis. Vol 29. New York: Plenum Press; 1986.

55. Milella E, Cosentino F, Licciulli A, Massaro C. Preparation and characterisation of titania/hydroxyapatite composite coatings obtained by sol-gel process. Biomaterials. 2001;22(11):1425-1431.

56. Zhuo ZH, Zhou PL, Yang SP, Yu XB, Yang LZ. Controllable synthesis of hydroxyapatite nanocrystals via a dendrimer-assisted hydrothermal process. Mater Res Bull. 2007;42(9):1611-1618.

57. Aryal S, Remant Bahadur KC, Dharmaraj N, Kim KW, Kim HY. Synthesis and characterisation of hydroxyapatite using carbon nanotubes as a nano-matrix. Scripta Mater. 2006;54:131-135.

58. Saeri MR, Afshar A, Ghorbani M, Ehsani N, Sorrell CC. The wet precipitation process of hydroxyapatite. Mater Lett. 2003;57:4064-4069.

59. Afshar A, Ghorbani M, Ehsani N, Saeri MR, Sorrell CC. Some important factors in the wet precipitation process of hydroxyapatite. Mater Design. 2003;24:197-202.

60. Wang YJ, Chen JD, Wei K, Zhang SH, Wang XD. Surfactant-assisted synthesis of hydroxyapatite particles. Mater Lett. 2006;60:3227-3231.

61. Beckett EL, Lawrence NS, Tsai YC, Davis J, Compton RG. Bioanalytical utility of sonovoltammetry. J Pharm Biomed Analysis. 2001; 26(5-6):995-1001.

62. Perusich SA, Alkire RC. Ultrasonically induced cavitation studies of electrochemical passivity and transport mechanisms. J Electrochem Soc. 1991;138(3):708-713.
International Journal of Nanomedicine

\section{Publish your work in this journal}

The International Journal of Nanomedicine is an international, peerreviewed journal focusing on the application of nanotechnology in diagnostics, therapeutics, and drug delivery systems throughout the biomedical field. This journal is indexed on PubMed Central,

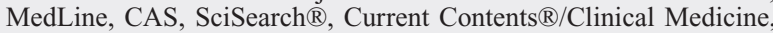

\section{Dovepress}

Journal Citation Reports/Science Edition, EMBase, Scopus and the Elsevier Bibliographic databases. The manuscript management system is completely online and includes a very quick and fair peer-review system, which is all easy to use. Visit http://www.dovepress.com/ testimonials.php to read real quotes from published authors. 